\title{
Balloon Sinuplasty
}

\author{
Joon Ho Kim and Sang Duck Lee \\ HANA ENT HOSPITAL, Seoul, Korea
}

\section{풍선카테터 부비동확장술}

\author{
김 준 호.이 상 덕 \\ 하나이비인후과병원
}

\author{
Received February 11, 2015 \\ Revised February 24, 2015 \\ Accepted February 28, 2015 \\ Address for correspondence \\ Sang Duck Lee, MD, PhD \\ HANA ENT HOSPITAL, \\ 245 Yeoksam-ro, Gangnam-gu, \\ Seoul 135-514, Korea \\ Tel +82-2-6925-1111 \\ Fax +82-2-3452-1495 \\ E-mail 1sd1347@hotmail.com
}

Balloon sinuplasty (BSP) is a newly developed catheter-based technique for dilating sinus ostia to improve sinus ventilation and drainage. BSP has been in clinical use since 2005, but there has been many debates and criticism between early movers and mainstream doctors. But, recently, many evidences strongly support its safety, efficacy, and growing popularity among patients and physicians. The objective of this clinical review is to present its theoretical background, technical considerations, and treatment outcomes. BSP will be an additional tool for treating sinusitis, either alone or with conventional sinus surgery technique.

Korean J Otorhinolaryngol-Head Neck Surg 2015;58(7):456-62

Key Words Balloon catheter dilation - Balloon sinuplasty · Endoscopic sinus surgery · Rhinosinusitis.

\section{서 론}

만성 비부비동염은 아직까지 일차 진료에서 가장 흔하게 접하게 되는 만성질환 중 하나이며, 부비동내시경수술(endoscopic sinus surgery)은 만성 비부비동염의 수술적 치료 중 현재까지 가장 효과적인 방법으로 받아들여지고 있다. 특히 30 여 년 이상 시행되면서 부비동내시경수술의 개념과 메커니 즘, 그리고 기본적인 수술 원칙이 어느 정도 정립되었고, 정상 적인 점막을 보호하기 위한 through cutting forceps, 미세절삭 기(microdebrider) 등 수술을 위한 도구들의 발달로 인해 보 다 정교하게 정상구조를 보존하며 수술을 시행할 수 있게 되 었다. 부비동내시경수술이 안전하고 효과적인 치료법으로 널 리 인정받고 있지만, 한편으로는 침습적인 수술이기 때문에 그로 인한 통증 및 출혈의 위험성이 있고 특히, 드물지만 안 구 손상이나 뇌척수액비루 등의 위험한 합병증을 약 1 3\% 가량에서 동반할 수 있는 단점을 지니고 있다. ${ }^{1,2}$ 또한 수술 자체가 부비동의 비가역적인 변화를 만들기 때문에 성공적 인 수술이 이루어진 후에도 정상적인 부비동의 생리와는 차이
가 있을 수 있으며, 이로 인해 환자의 삶의 질이 오히려 수술 전 보다 저하되기도 한다.

풍선카테터 부비동확장술(balloon sinuplasty)은 2005년 경부터 미국에서 시작하여 현재 전세계적으로 시행되고 있으 며, 소화기, 비뇨기, 심혈관 질환의 치료에 성공적으로 적용되 고 있는 카테터 기반치료(catheter based treatment)를 부비동 염의 치료에 적용한 것이다(Fig. 1). 상악동, 전두동, 혹은 접형 동 등 단일 자연배출구를 가지는 부비동의 자연배출구를 조 직손상이나 제거 없이 안전하게 확장하여 환자의 증상 개선 및 삶의 질 개선을 도모할 수 있으며, 기구 자체의 특성으로 인해 balloon sinuplasty는 일반적으로 기존의 수술에 비해 출혈 및 통증이 적고, 회복기간이 짧아 일상생활로의 복귀가 빠르다. ${ }^{34)}$ 하지만 단일배출구를 갖지 않는 사골동에는 직접 적으로 적용할 수 없기 때문에 사골동 병변에 대해 기존의 부비동내시경수술을 같이 적용하는 경우도 있다. ${ }^{5,6)}$ 그러므 로 이러한 balloon sinuplasty 자체가 완전히 새로운 수술이라 기보다 부비동입구부를 balloon sinuplasty 혹은 부비동풍 선확장법(balloon catheter dilation technique)이라는 방법을 


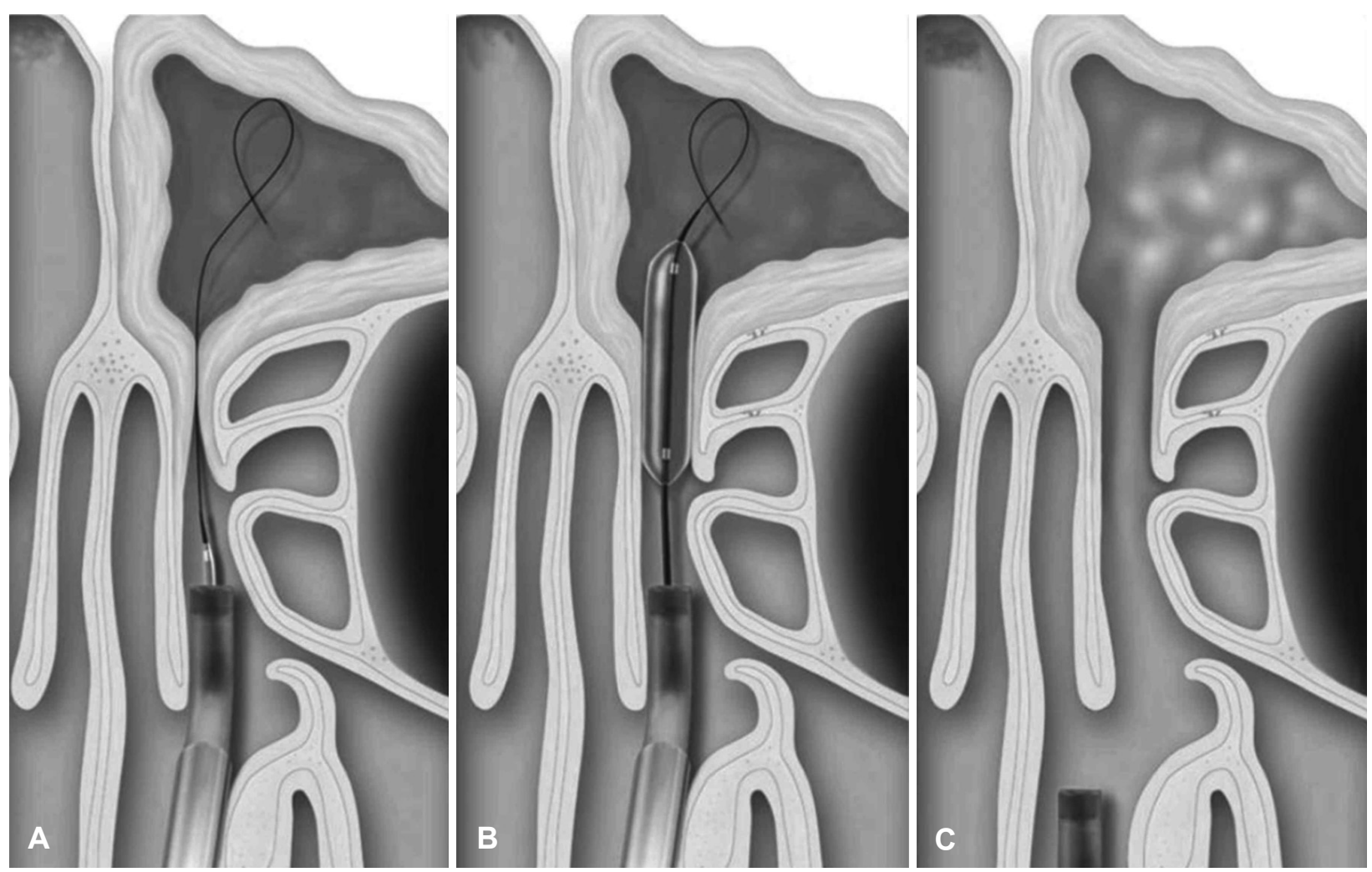

Fig. 1. Left frontal sinus balloon sinuplasty sequence. Guide catheter in position, guide-wire advanced into left frontal sinus (A). Balloon catheter positioned across ostium and inflated. Bony micro-fractures around the inflated ostium (B). Dilated ostium and balloon catheter removed (C). Reprinted with permission from Acclarent, Inc.

이용하여 확장해주는 기법으로 이해하는 것이 필요하다. 최근 에는 기구의 발전과 더불어 전신마취하에 수술실에서 시행되 던 것에서 나아가 외래에서 간단한 국소마취만으로도 안전 하게 시행할 수 있게 되어 그 임상적 유용성이 증대되었다. 본 논문에서는 풍선카테터 부비동확장술의 이론적 배경과 현재 까지의 임상결과, 그리고 실제 시행시의 방법 및 주의점에 대 해 논의하고자 한다.

\section{풍선카테터 부비동확장술의 역사와 치료 성적}

흔히 비부비동염의 발생기전 중 하나로 부비동 자연공의 폐쇄가 주로 언급되고 있다. 이러한 질환 발생의 기전은 기존 의 카테터 기반 치료가 이미 기존 수술치료를 상당부분 대체 한 심혈관 질환과 비슷하다. 또한 코를 통해 카테터를 삽입 하는 것이 비교적 안전하게 시행할 수 있다는 점, 점막을 보 존하면서 폐쇄부위만 확장시켜 줌으로써 부비동의 기능은 회 복하되 수술로 인한 출혈, 조직 손상, 반흔의 문제를 해결 할 수 있다는 점이 balloon sinuplasty 개발의 배경이 되었다. 부 비동의 해부 생리 중 구상돌기(uncinate process)를 포함한 정
상 구조를 보존함으로써 얻을 수 있는 기능적 장점이 있고, 또 한 기존의 부비동내시경수술 중 큰 상악동개방술(middle meatal antrostomy) 후 일산화질소(nitric oxide)의 분포 및 호흡 시 기류변화로 점막 기능의 변화가 발생하는 점 역시 balloon sinuplasty를 포함한 최소 침습적 수술의 장점에 대한 이론적 배경이 될 수 있다. ${ }^{7)}$

Balloon sinuplasty는 캘리포니아의 Acclarent, Inc.사에서 개발하여 2005년 The Food and Drug Administration 승인 을 받으면서 임상적용이 시작되었다. Balloon sinuplasty에 관 한 임상 보고는 2006년부터 시작되었으며, 특히 2006년 안전 성 확인을 위한 사체 연구(cadaver study)에서 안와와 뇌기저 부의 손상 없이 기존의 수술에 비해 비교적 적은 점막 손상 으로 부비동 입구부를 확장할 수 있었다고 보고하여 실제 임 상 적용의 가능성을 확인하였고, ${ }^{8)}$ 이후 Brown과 Bolger ${ }^{9}$ 가 최초로 10 명의 환자에서 balloon sinuplasty를 적용하여 합병 증 없이 성공적으로 시술함을 보고하였다. 이후로 여러 임상 연구를 통해 안정성이 검증되며 현재 많은 환자들에게 적용 되고 있다. 특히 2007년과 2008년에 걸쳐 이루어진 다기관 전향적 연구인 CLinical Evaluation to confirm sAfety and efficacy of sinuplasty in the paRanasal sinuses 연구(CLEAR 
study)를 통해 시술 후 24주, 1년, 2년까지의 경과관찰을 시 행한 결과가 보고되었다. ${ }^{10-12)}$ 이 중 2년까지 장기 관찰한 논문 에서는 65 명, 195 개의 부비동에 대해 balloon sinuplasty를 시 행하여 특별한 합병증 없이 $85 \%$ 정도의 환자에서 주관적 증 상 호전을 보였고, 재수술은 6명(9.2\%)의 환자, 7 개의 부비동 (3.6\%)에 대해 시행하였다고 보고하였다. ${ }^{12)}$ 이후로도 Levine 등 ${ }^{5}$ 이 1036명의 환자에서 3276개의 부비동에 대해 balloon sinuplasty를 시행한 대규모 다기관 후향적 연구를 보고하면 서, 전체 환자의 $95.2 \%$ 에서 증상호전 및 $1.3 \%$ 의 재수술률 등 성공적인 결과를 보여주었다. 하지만 2013년 Tomazic 등히이 발표한 연구에서는 45 명의 환자, 112 개의 부비동에 대해 balloon sinuplasty를 시도하여 $65 \%$ 이상의 시술 실패를 보고하 기도 하였다. 이 논문의 결과는 기존의 보고 및 실제 임상과 는 많은 차이가 있는 것으로, 기존 부비동내시경수술의 관점 에서 balloon sinuplasty를 적용하였을 때 성공률 자체뿐 아 니라 임상에서 논란의 여지가 있음을 보여주었다. 하지만 최 근에는 balloon sinuplasty를 수술 자체가 아니라 비부비동 염의 수술적 치료 중 특히 자연배출구를 넓히면서 주변 조직 손상을 최소화하기 위한 도구로 이해하고 받아들이게 되면 서 balloon sinuplasty 초기 논쟁의 절충점을 찾게 되었다. ${ }^{14}$ 또한 기구의 발전으로 인해 balloon sinuplasty 시행 초기에 C-arm 등을 이용한 형광투시 유도(fluoroscopic guide)하에 서 시행하던 것이 철조법(transillumination)을 이용한 fiberoptic guide-wire(Luma ${ }^{\mathrm{TM}}$, Acclarent Inc., Menlo Park, CA, USA)를 2009년경부터 이용하게 됨으로써 시술의 안정성과 유용성을 획기적으로 개선하게 되었다.

앞에서 언급한대로 balloon sinuplasty에 대한 연구는 초
기에는 사체연구나 임상연구를 통해 balloon sinuplasty의 안 전성과 임상 가능성에 대한 보고가 주로 시행되었다. 아직까 지 기존의 부비동내시경수술과의 정확한 무작위 대조 연구 (randomized controlled trial, RCT)는 많지 않으나, 2011년 Plaza 등)이 보고한 RCT 논문에서는 전두동의 병변에 대하 여 balloon sinuplasty와 내시경수술군에 대해 1년 추적관찰 결과를 비교하였다. 양 군에서 모두 증상 및 내시경 소견, $\mathrm{CT}$ 소견 모두 호전되었으며, 재수술률은 balloon sinuplasty군에 서 더 낮았다(6.25\% vs. 18.75\%). Cutler 등근 2013년 또 다른 balloon sinuplasty 기구 제조회사인 Entellus Medical, Inc. 사의 기구를 사용하여 92 명의 만성상악동염 환자군을 balloon sinuplasty군과 부비동내시경수술군으로 나누어 다기관 RCT 연구를 진행하였다. Balloon sinuplasty와 부비동내시경수술 군 모두에서 증상 점수가 호전되어 두 군이 비슷한 결과가 나 왔으나, 통증의 정도와 회복기간, 술 후 치료횟수(debridement) 에서는 balloon sinuplasty군에서 유의하게 좋은 결과를 보 고하였다.

Balloon sinuplasty로 인한 합병증에 대한 보고도 있다. Levine 등 $^{5}$ 이 2008년 보고한 논문에서 2건의 뇌척수액루 (cerebrospinal fluid leakage)를 보고하였으나, 이는 balloon sinuplasty 도중 사골동의 내시경수술을 시행하는 중에 발생 한 것으로 balloon sinuplasty로 인한 직접적인 합병증으로 볼 수는 없다. 하지만 전두동에 대한 balloon sinuplasty를 시행한 환자에서 사골동 천정부의 뇌척수액루를 보고한 증 례보고 ${ }^{15}$ 가 있으며, 시술 후 안와상부의 골막하혈종이 발생 후 흡수된 사례, ${ }^{16)}$ 그리고 안와지판이 골절된 사례 ${ }^{17)}$ 등이 있 다. 물론 기존의 부비동내시경수술과 비교하였을 때 balloon

Table 1. Complications of functional endoscopic sinus surgery (FESS) and balloon sinuplasty (BSP)

\begin{tabular}{|c|c|c|c|c|}
\hline Author (year) & Type of study & $\begin{array}{l}\text { Type of } \\
\text { surgery }\end{array}$ & $\begin{array}{l}\text { Number } \\
\text { of patients }\end{array}$ & Complications \\
\hline May, et al. ${ }^{24)}(1994)$ & Retrospective & FESS & 2108 & $\begin{array}{l}0.85 \% \text { major complications } \\
6.9 \% \text { minor complications }\end{array}$ \\
\hline Dalziel, et al. ${ }^{25)}$ (2006) & Meta-analysis & FESS & 12329 & $\begin{array}{l}0-1.5 \% \text { major complications } \\
1.1-20.8 \% \text { minor complications }\end{array}$ \\
\hline Stankiewicz, et al. ${ }^{2)}$ (2011) & Retrospective & FESS & 3402 & $3.1 \%$ complication rate \\
\hline Ramakrishnan, et al. ${ }^{1)}$ (2012) & $\begin{array}{l}\text { Retrospective, } \\
\text { data base review }\end{array}$ & FESS & 62823 & $\begin{array}{l}\text { Overall } 1 \% \text { major complications } \\
\text { (CSF leak, orbital injury, hemorrhage) }\end{array}$ \\
\hline Bolger, et al. $^{10)}(2007)$ & Prospective, multicenter & BSP & 115 & 0 serious events \\
\hline Levine, et al. ${ }^{5)}$ (2008) & $\begin{array}{l}\text { Retrospective, } \\
\text { multicenter registry }\end{array}$ & BSP/hybrid & 1036 & $\begin{array}{l}0 \text { balloon-only-related complications } \\
0.2 \% \text { CSF leaks in hybrid group }\end{array}$ \\
\hline Plaza, et al. $\left.{ }^{6}\right)(2011)$ & $\begin{array}{l}\text { Prospective, randomized } \\
\text { controlled }\end{array}$ & BSP/hybrid & 40 & 0 major complications \\
\hline Cutler, et al. ${ }^{3)}$ (2013) & $\begin{array}{l}\text { Prospective randomized } \\
\text { controlled }\end{array}$ & $\mathrm{BSP} / \mathrm{FESS}$ & 92 & No complications \\
\hline Karanfilov, et al. ${ }^{18)}$ (2013) & Prospective, multicenter & BSP & 203 & 1 adverse event, resolved \\
\hline
\end{tabular}

CSF: cerebrospinal fluid 
sinuplasty의 합병증은 상당히 낮으며, 특히 중대 합병증의 발생은 흔치 않다(Table 1).

최근에는 balloon sinuplasty를 이용하여 수술실이 아닌 외 래 진료실에서 국소마취만으로 시행하는 시도가 많이 보고 되고 있으며, 적응증을 잘 선택할 경우 환자의 만족도를 높 일 수 있다. Karanfilov 등 ${ }^{18}$ 은 외래 진료실에서 국소마취 하에 203명의 환자에서 balloon sinuplasty를 시행한 다기관 전향 적 연구에서 안정성이 높고 환자의 순응도가 높았고, 미국에 서의 의료환경상 시술 혹은 수술로 인한 비용절감 효과가 높 음을 보고하였다.

\section{풍선카테터 부비동확장술의 적응증}

기존의 부비동내시경수술과 마찬가지로 약물치료에 반응 하지 않는 재발성의 비부비동염이 balloon sinuplasty의 적응 증이 될 수 있다. 아직까지 공통적이고 합의되어 적용할 수 있 는 적응증은 없지만, 2007년 발표된 논문에서는 광범위한 부 비동 용종(extensive sinonasal polyps), 광범위한 과거수술력 (extensive previous sinonasal surgery), 광범위골형성(extensive sinonasal osteoneogenesis), 안면외상력(facial trauma that distorted sinus anatomy), 섬모기능이상(ciliary dysfunction), 임신(pregnancy) 등의 환자를 제외한 비부비동염 환자에서 연구가 진행되었다. ${ }^{10)}$ 따라서 일반적으로 약물치료 에 반응하지 않는 수술적 치료의 대상이 되는 비부비동염 환 자군 중 경도 혹은 중등도의 염증을 동반하거나 재발성 증상 (recurrent symptom)이 있는 환자군이 balloon sinuplasty의 적응증이 될 수 있겠다. 오히려 실제 임상에서는 balloon sinuplasty만으로 해결되지 않을 환자들을 잘 선별하여 제외하는 것이 중요하다. 특히 시술 전 부비동내의 골부 혹은 점막 병 변의 중증도를 약물치료의 반응정도나 CT 등을 통해 확인 하고 염증의 정도가 심할 것으로 예상되는 경우 혹은 해부학 적 구조 변형이 심한 경우는 balloon sinuplasty만으로 충분 한 해결이 되지 않을 수 있으니 주의한다. 또한 부비동의 입구 부, 특히 전두동 입구부의 해부학적 구조가 매우 좁거나 염증 으로 인해 뼈의 과형성 및 변형이 심한 경우 풍선을 팽창시킬 때 의도하지 않은 부분의 골절로 인해 합병증이 일어날 가능 성이 있다. 이전에 부비동내시경수술 후 재발한 경우에는 일 반적으로 부비동 입구부가 개방되어있거나 개방 후 다시 협착 되어 있는 경우가 흔하고, 부비동내의 염증이 상대적으로 중 증인 경우가 많으므로 balloon sinuplasty만으로는 충분하지 않은 경우가 많다.

일부 환자군에서는 balloon sinuplasty와 더불어 사골동 병 변에 대해 기존의 부비동내시경수술을 같이 시행하는 hybrid technique을 시행함으로써 balloon sinuplasty만으로 호전되 기 힘든 사골동 병변이 동반된 비부비동염 환자에게도 적용을 넓혀가고 있다. ${ }^{5,6}$ 또한 수술 후 출혈이 적고 환자의 불편감 및 전신 상태에 미치는 영향이 적은 특징으로 인해 소아나 고령 인 환자, 임산부, 면역 기능이 저하된 환자, 혹은 다른 이유로 기존의 부비동내시경수술이 불가한 환자에서 balloon sinuplasty를 통해 보다 효과적인 결과를 얻을 수도 있다. 실제로 Ramadan 등 19,20 은 소아에서 balloon sinuplasty를 시행하여 합병증 없이 좋은 결과를 보고하였고, 중환자실 치료나 면역기 능이 저하되어 있는 환자군을 대상으로 balloon sinuplasty를 통해 성공적인 치료 결과를 보이기도 하였다. ${ }^{21,22)}$ 또한 급성 비 부비동염의 합병증으로 뇌농양이 동반된 소아환자에서 적용 한 사례도 보고되었다. ${ }^{23)}$ 하지만 이러한 환자군은 실제 임상 에서 흔히 접하지는 않고 공통된 적응증이 존재하지 않으므 로 환자 개개의 경우에 따라 신중한 접근이 필요하겠다.

\section{풍선카테터 부비동확장술의 기구}

풍선카테터 부비동확장술에 이용되는 기구는 기본적으로 부비동내시경수술 시 사용하게 되는 기구에 풍선확장술을 위 한 추가 기구들로 구성된다. 현재 미국에서 주로 사용되는 기 구는 앞에서 여러번 언급된 Acclarent(Menlo Park, CA, USA) 사에서 출시된 Relieva $\mathrm{Spin}^{\mathrm{TM}}$ 과 Entellus Medical(Maple Grove, $\mathrm{MN}, \mathrm{USA}$ )사에서 나온 $\mathrm{XprESS} \mathrm{S}^{\mathrm{TM}}$ 등이 있다. 두 회사 모두 balloon sinuplasty의 이론적 원칙은 동일하지만 기구 회 사에 따라 실제 임상 적용 시 기술적 차이가 조금씩 있다. 현재 (2015년 2월 기준) 한국에서는 Acclarent사의 제품만이 등록 되어 사용할 수 있으므로 Acclarent사의 제품을 기준으로 설 명하고자 한다.

이전 모델(Relieva Solo Pro)의 구성을 살펴보면 일회용으로 흡입 기능을 가지고 있는 여러 각도의 유도카테터(guide catheters), 철조법을 이용하기 위한 fiberoptic flexible guide-wire, 풍선카테터(sinus balloon catheters), 압력계가 장착된 팽창 기구(inflation device)가 필요하다. 초기에는 투시조영법(fluoroscopy)을 이용하여 풍선의 위치를 C-arm 등을 이용하여 확인하였으나, 최근에는 fiberoptic guide-wire(LUMA $\left.{ }^{\mathrm{TM}}\right)$ 를 이용하게 됨으로써 일부 필요한 경우에만 C-arm을 사용하 게 되었다. 유도카테터는 0 도에서부터 110 도까지 다양한 카테 터가 있으며(0도, 30도, 70도, 90도, 110도) 각 부비동에 따라 다른 유도카테터를 이용하게 된다. 풍선카테터는 풍선의 직 경과 길이에 따라 다양하게 사용되고 있으며, 성인의 경우에 는 직경 $6 \mathrm{~mm} \times$ 길이 $16 \mathrm{~mm}$ 가 주로 사용된다. 위에서 언급 한 기구들을 조합하여 한 손으로 내시경과 풍선확장기구를 

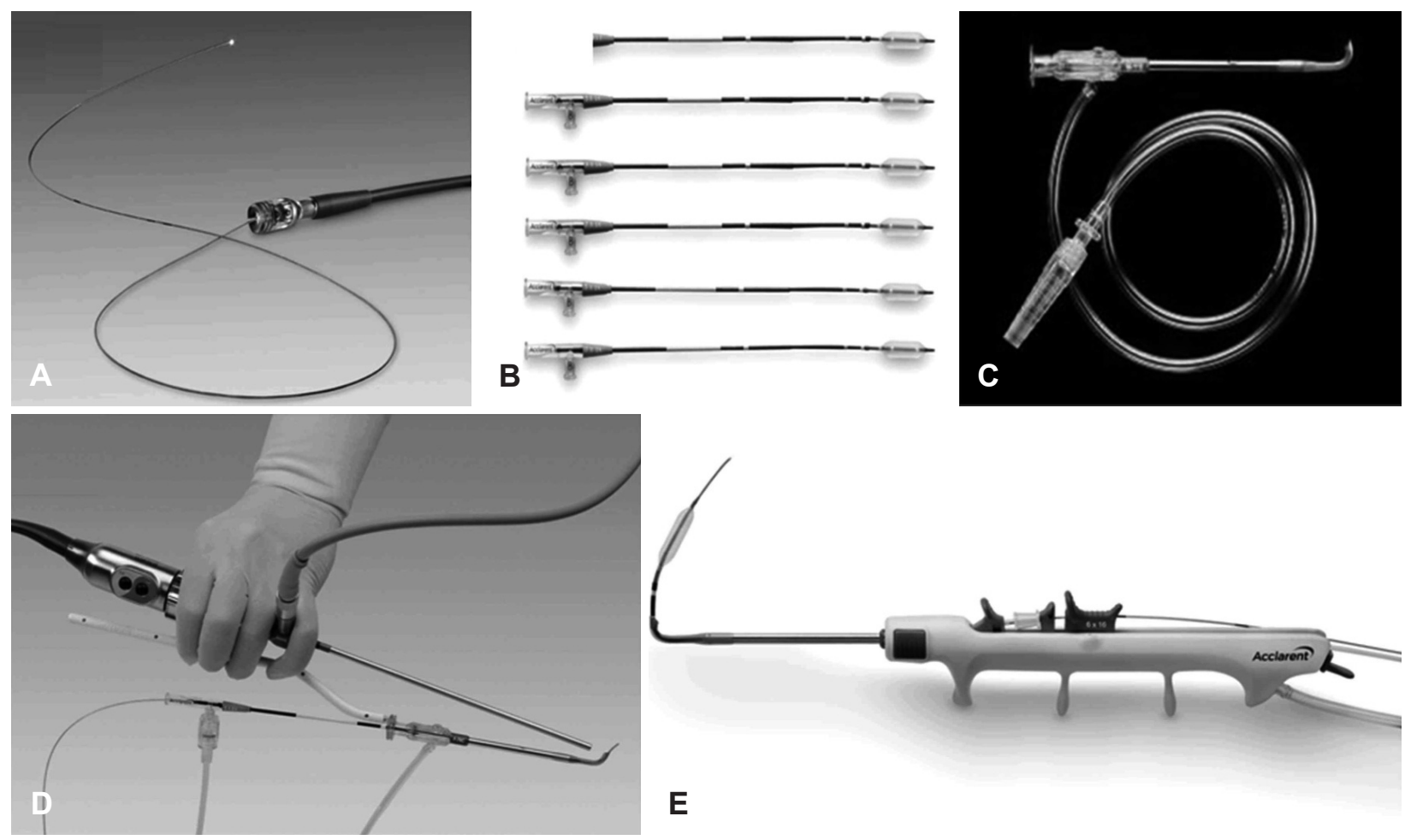

Fig. 2. Balloon sinuplasty equipment. Relieva Luma Sentry ${ }^{\circledR}$ sinus illumination system (A). Relieva Solo Pro ${ }^{\mathrm{TM}}$ sinus balloon catheter (B). Sinus guide catheters (C). 1st generation balloon sinuplasty system. The device is integrated with balloon, guide catheter, illumination guide wire and sidekick holder (D). Relieva ${ }^{\circledR} \operatorname{Spin}^{\mathrm{TM}}, 2$ nd generation system (E). Reprinted with permission from Acclarent, Inc.
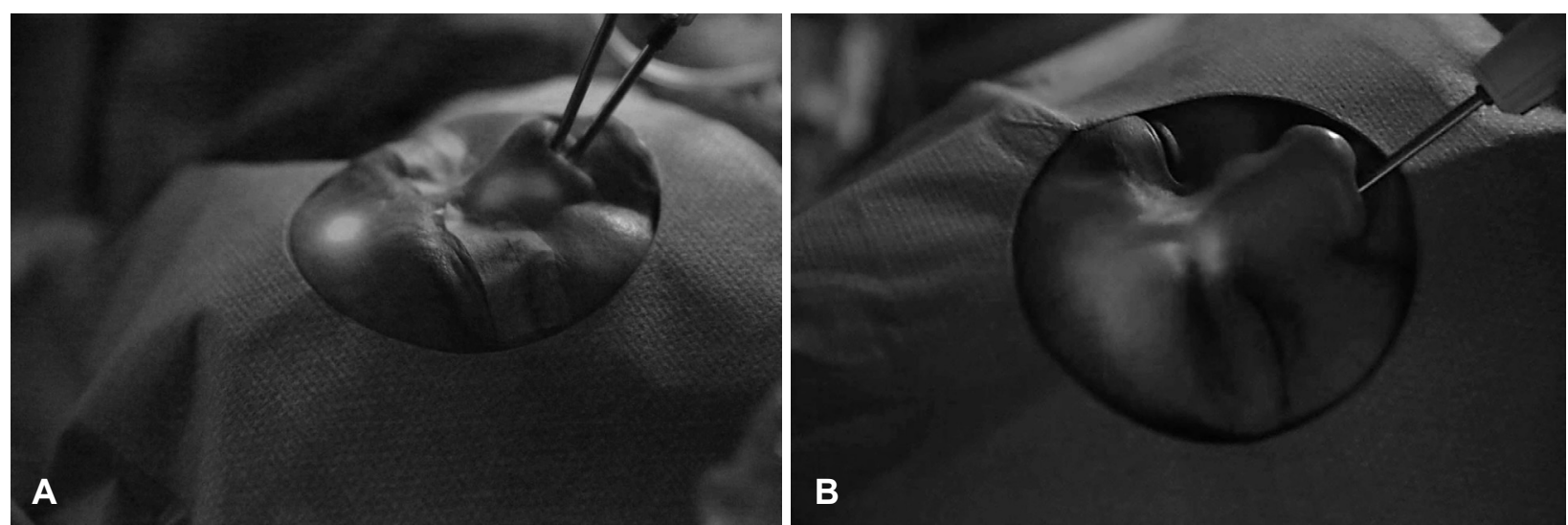

Fig. 3. Surgical photograph showing transillumination pattern of frontal sinus. Focal, spot-like transillumination of the frontal sinus, confirming correct placement of the guide-wire inside frontal sinus (A). Diffuse transillumination pattern, meaning guide-wire around ethmoid area, frontal recess or supraorbital cell (B).

동시에 잡으면서 guide-wire를 조작하여야 했으나, 최근에는 이를 한 손으로 조작할 수 있는 기구(Relieva ${ }^{\circledR} \mathrm{Spin}^{\mathrm{TM}}$ )가 개발 되어 주로 사용되고 있다(Fig. 2).

\section{풍선카테터 부비동확장술의 방법}

1:10만 에피네프린을 포함한 $1 \%$ 리도카인을 이용하여 국소 침윤 마취 및 cotton pledget을 이용한 국소마취를 시행한 다. 환자의 상태에 따라 다르겠으나 일반적인 국소마취만으
로도 충분한 경우가 대부분이다. 유도카테터(guide catheter) 를 내시경 시야 하에 병변의 입구에 위치시키고 guide-wire를 유도카테터를 통과하여 병변부로 삽입한다. 전두동의 경우 유도카테터는 주로 70 도를 사용하며, 대개 중비갑개의 1/2지 점 높이, 사골포의 앞쪽에 위치하게 된다. 구상돌기의 상부부 착부위 및 CT상 환자의 해부학적 구조를 고려하여 guidewire의 진입부위를 내측 및 외측으로 전환하여 진입을 시도 한다. Guide-wire가 잘 들어갔을 경우 전두동의 전벽에 국소 적인 철조현상(focused transillumination)을 확인할 수 있게 


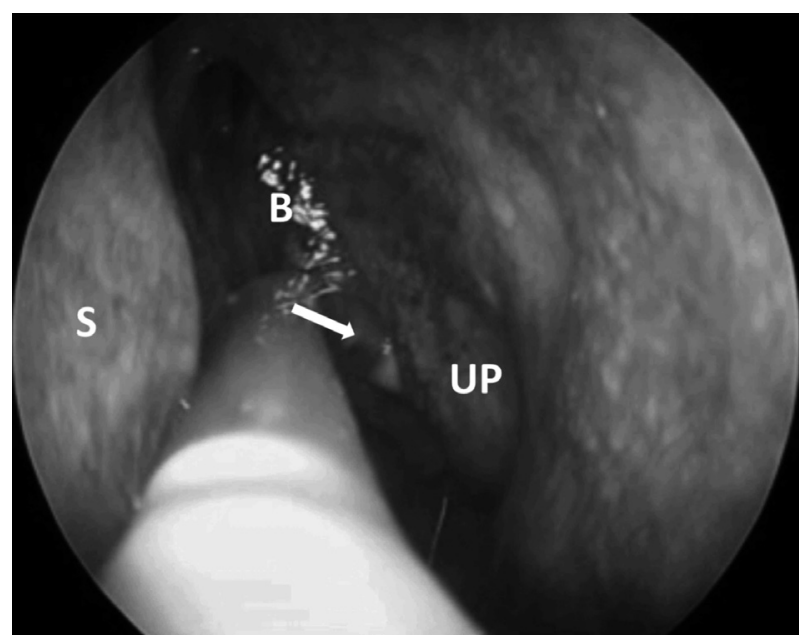

Fig. 4. Endoscopic view of guide catheter positioning for left side maxillary sinus balloon sinuplasty. The guide catheter tip is positioned between uncinate process and bulla ethmoidalis. Note 4 o'clock direction of guide catheter tip (white arrow). S: septum, B: bulla ethmoidalis, UP: uncinate process.

된다(Fig. 3A). 특히 전두동 내부에서 wire를 움직여 전두동 내로 잘 진입하였는지 다시 한 번 확인하고, 전두동의 크기 나 형태를 환자의 $\mathrm{CT}$ 와 비교하여 확인할 수도 있다. 전두동 으로 진입되지 않고 상안와봉소(supraorbital cell)나 전두와 봉소(frontal recess cell) 혹은 사골동 등으로 진입된 경우, 국 소적인 철조현상이 아니라 넓게 퍼져보이는(diffuse transillumination) 철조현상(Fig. 3B)이 나타나므로 정확한 위치를 꼭 확인하고 풍선팽창을 시행하도록 주의한다. 상악동의 경우 유도카테터는 90도 혹은 110도를 사용하게 되며 구상돌기 (uncinate process)와 사골포 사이에 위치하게 된다. 특히 자 연공의 위치와 방향을 고려하여 유도카테터의 굽어진 끝으 로 구상돌기를 앞쪽으로 조금 당겨 카테터의 위치가 전방, 하방, 외측으로 향하게 한다. 일반적으로 우측 상악동의 경 우 유도 카테터가 7시에서 8시 방향, 좌측 상악동의 경우 4시 에서 5시 방향이 된다(Fig. 4). 이후 guide-wire를 유도카테 터를 통해 진입시키며 상악동 내부로 잘 진입이 된 경우에는 상악전벽이나 견치와(canine fossa), 혹은 입천장 부위에서 철 조현상을 관찰하여 확인한다(Fig. 5). 접형동의 경우 유도카 테터는 0도 혹은 30도를 사용하며, 외부에서 철조현상을 확 인하기 힘들기 때문에 특히 주의를 요한다. 유도카테터는 중 비갑개, 상비갑개와 비중격 사이의 공간에 위치하며, guidewire를 접형동에 성공적으로 진입시켰을 경우라면 비강 및 비인두 등에서 guide-wire 및 광원이 보이지 않음을 확인하 여야 한다. 일부에서는 내시경 광원을 모두 줄인 뒤 접형동 전 벽 후방 내측에서 희미한 불빛(Jack-O-Lantern pattern)을 확인할 수 있다.

각 부비동에 guide-wire가 잘 진입한 것이 확인되면 유도

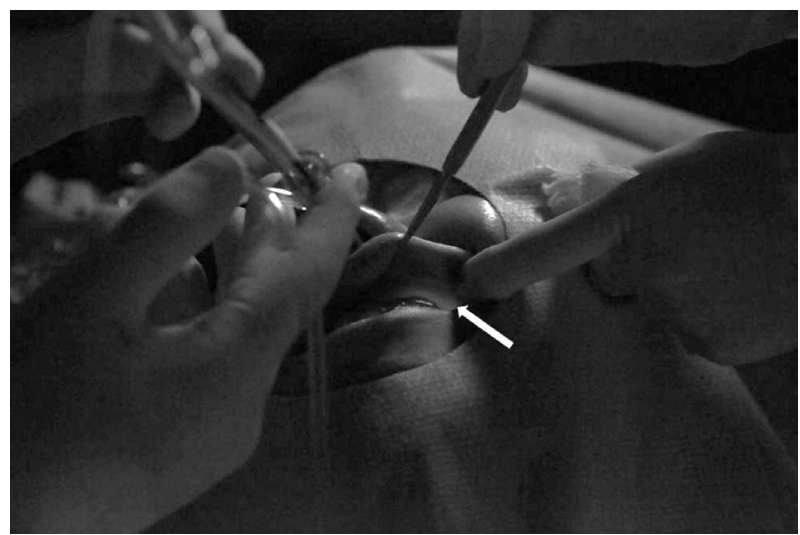

Fig. 5. Surgical photograph showing transillumination pattern of maxillary sinus. Note transillumination pattern around canine fossa area (white arrow).

카테터를 잘 고정한 상태에서 풍선카테터를 전진시키게 된 다. 술 전 확인한 CT와 내시경상의 병변 부위를 고려하여 풍 선을 위치시키며, 풍선팽창(balloon inflation)을 시행한다. 풍 선팽창시 기구 내에는 증류수 혹은 식염수를 채워 보조의 혹 은 간호사가 시행한다. 팽창시에는 천천히 8 12기압까지 가압 한 이후 병변의 정도에 따라 수초간 유지하고 이후 빠르게 감 압한다. 병변의 범위와 부비동의 해부학적 구조에 따라 근위 부 혹은 원위부로 풍선을 이동시켜 반복 시행한다. 이후 부비 동내의 분비물을 배출시키기 위해서는 부비동세척카테터(sinus irrigation catheter)를 이용하여 세척을 시행할 수 있다. 시술 후에는 가볍게 분비물과 출혈을 흡입소독하며 부비동 내시경수술이나 기타 다른 수술을 같이 시행한 경우가 아니 라면 패킹없이 시술을 끝낸다.

\section{결 론}

비부비동염은 아직까지 일차 진료에서 굉장히 흔하게 접하 게 되는 질환이며, 이로 인한 환자들의 불편감과 삶의 질 저하 역시 심각하다. 약물치료에 반응하지 않는 비부비동염의 경우 수술적 치료의 대상이 되며, 기존 부비동내시경수술은 최근까 지 만성 비부비동염의 표준치료로 비교적 좋은 결과를 보여주 고 있다. 하지만 일부 합병증이나 수술로 인한 환자의 불편감, 그리고 피할 수 없는 일부 재발 등은 만족스럽지 못한 부분이 다. 최근 시행되고 있는 풍선카테터 부비동확장술(balloon sinuplasty)은 부비동입구부의 병변을 해결하기 위한 최소침 습적인 도구로써 모든 부비동내시경수술을 대체하기 위한 수 술법이 아니며 일부 잘 선택된 적응증의 환자에게 사용된다 면 분명 효과적인 도구이자 해결책이 될 수 있다. 앞으로 보다 많은 경험과 임상 결과가 쌓이고 기술적 발전이 이루어진다면 비부비동염의 치료에 있어 balloon sinuplasty의 역할은 최소 
침습(minimally invasive)과 기능보존(functional preservation)이라는 시대적 흐름과 연관되어 보다 확대될 것이다.

\section{REFERENCES}

1) Ramakrishnan VR, Kingdom TT, Nayak JV, Hwang PH, Orlandi RR. Nationwide incidence of major complications in endoscopic sinus surgery. Int Forum Allergy Rhinol 2012;2(1):34-9.

2) Stankiewicz JA, Lal D, Connor M, Welch K. Complications in endoscopic sinus surgery for chronic rhinosinusitis: a 25 -year experience. Laryngoscope 2011;121(12):2684-701.

3) Cutler J, Bikhazi N, Light J, Truitt T, Schwartz M; REMODEL Study Investigators. Standalone balloon dilation versus sinus surgery for chronic rhinosinusitis: a prospective, multicenter, randomized, controlled trial. Am J Rhinol Allergy 2013;27(5):416-22.

4) Sillers MJ, Melroy CT. In-office functional endoscopic sinus surgery for chronic rhinosinusitis utilizing balloon catheter dilation technology. Curr Opin Otolaryngol Head Neck Surg 2013;21(1):17-22.

5) Levine HL, Sertich AP 2nd, Hoisington DR, Weiss RL, Pritikin J; PatiENT Registry Study Group. Multicenter registry of balloon catheter sinusotomy outcomes for 1,036 patients. Ann Otol Rhinol Laryngol 2008;117(4):263-70.

6) Plaza G, Eisenberg G, Montojo J, Onrubia T, Urbasos M, O'Connor C. Balloon dilation of the frontal recess: a randomized clinical trial. Ann Otol Rhinol Laryngol 2011;120(8):511-8.

7) Catalano PJ. Balloon dilation technology: let the truth be told. Curr Allergy Asthma Rep 2013;13(2):250-4

8) Bolger WE, Vaughan WC. Catheter-based dilation of the sinus ostia: initial safety and feasibility analysis in a cadaver model. Am J Rhinol 2006;20(3):290-4.

9) Brown CL, Bolger WE. Safety and feasibility of balloon catheter dilation of paranasal sinus ostia: a preliminary investigation. Ann Otol Rhinol Laryngol 2006;115(4):293-9; discussion 300-1.

10) Bolger WE, Brown CL, Church CA, Goldberg AN, Karanfilov B, Kuhn FA, et al. Safety and outcomes of balloon catheter sinusotomy: a multicenter 24-week analysis in 115 patients. Otolaryngol Head Neck Surg 2007;137(1):10-20.

11) Kuhn FA, Church CA, Goldberg AN, Levine HL, Sillers MJ, Vaughan $\mathrm{WC}$, et al. Balloon catheter sinusotomy: one-year follow-up-outcomes and role in functional endoscopic sinus surgery. Otolaryngol Head Neck Surg 2008;139(3 Suppl 3):S27-37.

12) Weiss RL, Church CA, Kuhn FA, Levine HL, Sillers MJ, Vaughan WC. Long-term outcome analysis of balloon catheter sinusotomy: two-year follow-up. Otolaryngol Head Neck Surg 2008;139(3 Suppl 3):S38-46.

13) Tomazic PV, Stammberger H, Braun H, Habermann W, Schmid C, Hammer GP, et al. Feasibility of balloon sinuplasty in patients with chronic rhinosinusitis: the Graz experience. Rhinology 2013;51(2): 120-7.

14) Melroy CT. The balloon dilating catheter as an instrument in sinus surgery. Otolaryngol Head Neck Surg 2008;139(3 Suppl 3):S23-6.

15) Tomazic PV, Stammberger H, Koele W, Gerstenberger C. Ethmoid roof CSF-leak following frontal sinus balloon sinuplasty. Rhinology 2010;48(2):247-50.

16) Winn BJ, Chan P, Krueger RA, Sires BS. Subperiosteal orbital hematoma after balloon sinus dilation. Ophthal Plast Reconstr Surg 2013;29(6):e162-4.

17) Özkiriş M, Akin İ, Özkiriş A, Aydin R, Saydam L. Orbital complication of balloon sinuplasty. J Craniofac Surg 2014;25(2): 499-501.

18) Karanfilov B, Silvers S, Pasha R, Sikand A, Shikani A, Sillers M, et al. Office-based balloon sinus dilation: a prospective, multicenter study of 203 patients. Int Forum Allergy Rhinol 2013;3(5):404-11.

19) Ramadan HH, McLaughlin K, Josephson G, Rimell F, Bent J, Parikh SR. Balloon catheter sinuplasty in young children. Am J Rhinol Allergy 2010;24(1):e54-6.

20) Ramadan HH, Bueller H, Hester ST, Terrell AM. Sinus balloon catheter dilation after adenoidectomy failure for children with chronic rhinosinusitis. Arch Otolaryngol Head Neck Surg 2012;138 (7):635-7.

21) Wittkopf ML, Becker SS, Duncavage JA, Russell PT. Balloon sinuplasty for the surgical management of immunocompromised and critically ill patients with acute rhinosinusitis. Otolaryngol Head Neck Surg 2009;140(4):596-8.

22) Di Girolamo S, Mazzone S, Di Mauro R, Giacomini P, Cantonetti M. Surgical management of rhinosinusitis in onco-hematological patients. Clin Exp Otorhinolaryngol 2014;7(4):302-6.

23) Roland LT, Wineland AM, Leonard DS. Balloon frontal sinuplasty for intracranial abscess in a pediatric acute sinusitis patient. Int $\mathrm{J}$ Pediatr Otorhinolaryngol 2015;79(3):432-4.

24) May M, Levine HL, Mester SJ, Schaitkin B. Complications of endoscopic sinus surgery: analysis of 2108 patients--incidence and prevention. Laryngoscope 1994;104(9):1080-3.

25) Dalziel K, Stein K, Round A, Garside R, Royle P. Endoscopic sinus surgery for the excision of nasal polyps: a systematic review of safety and effectiveness. Am J Rhinol 2006;20(5):506-19. 